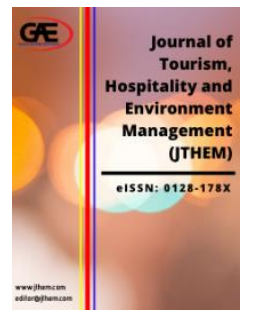

Journal of Tourism, Hospitality and Environment Management (JTHEM)

\title{
FOODSERVICE WAGING WAR AGAINST COVID-19 CRISIS AND THE OPPORTUNITY
}

\author{
Lim Soon Chow ${ }^{1}$ \\ 1 Faculty of Business and Finance, Universiti Tunku Abdul Rahman, Kampar, Malaysia \\ Email: joelim_s_chow@yahoo.com joelim_s_chow@yahoo.com
}

\section{Article Info:}

Article history:

Received date: 15.04 .2020

Revised date: 04.05 .2020

Accepted date: 06.05.2020

Published date: 10.06 .2020

To cite this document:

Lim, S. C. (2020). Foodservice Waging War Against Covid-19 Crisis and The Opportunity. Journal of Tourism, Hospitality and Environment Management, 5 (19), 41-49.

DOI: 10.35631/JTHEM.519004.

\begin{abstract}
:
COVID-19 outbreak is threatening the foodservice industry that caused the foodservice operators to shoulder the double burden of fixed cost and zero footfall during the pandemics episode. This best practice review is a simple and effective shortcut for food operators and worth adopting; meanwhile, all these practices provide food for thought by demonstrating what can be done and how to avoid any harm coming to individuals. This bird's eye view cultivates tactical ideas to policymaker and researcher in dealing with the epidemic episode.
\end{abstract}

Keywords:

COVID-19, Foodservice, Pandemic Crisis, Food Safety

\section{Introduction}

Unprecedented epidemic the COVID-19 shrouded the foodservice industry in the gloomsignificantly influence the foodservice industry, although it is an essential service for a living. The reduction in footfall due to the advocacy of social distancing to prevent the spread of COVID-19 to the community has etched into consumer's minds that self-health and selfprevention are essential.

No mercy granted by the global epidemic crisis the COVID-19; this has recognized as a severe epidemic that negatively impacts the entire world economy and people's well-being and behavioral change. World Health Organisation (WHO) officially announced it as "Pandemic" (WHO, 2020). Most of the industries are inescapable in this disease crisis episode. A bird's eye view on Asia; on 19 March 20 Malaysia has the fourth-highest number of COVID-19 Copyright (C) GLOBAL ACADEMIC EXCELLENCE (M) SDN BHD - All rights reserved 
confirmed cases (Ahmad, 2020) on the present situation; the foodservice industry greatly influenced by the technical-economic recession. Relevant authorities were putting numerous efforts to advocate the change of individual behavior to curb the spread of viruses. The implementation of social distancing practice, no human interaction, and personal hygiene optimally - besides, country-level implementing control measures to restrict people moving around the country. For instance, Malaysia implemented "Movement Control Order," and Singapore executed "Community Circuit Breaker," where all these controls imposed to lower the human interaction and reduce the infection opportunity. Besides, it limited the economic activities in the country.

Foodservice in nature involves extensive human interaction as consumers explore various touchpoints along the dining journey. Hence, it severely affected the marketing activities as the footfall downturns to zero, and it is more important than ever to have a business continuity plan to overcome this critical period. While the pharmaceutical and healthcare industry interventions to narrow the spread of COVID-19, business management can provide remarkable insights for managing customers' expectations, and it influences. Therefore, this editorial could help in generating ideas for making improvements and developing new ways of foodservice operation to alleviate the spread of COVID-19. Two significant categories discussed below comprise the best practices during the interim preventive period, and the opportunity unveiled its anew reference to devote future studies. Policymakers could leverage this preliminary review to structure the precautionary measure and control of the epidemic crisis precisely in the foodservice sector.

\section{Epidemic in Foodservice}

Historically, in foodservice epidemics generally related to foodborne diseases, which well, defined by WHO (2008) as any "diseases of an infectious or toxic nature caused by consumption of food." On the other hand, the outbreak of the foodborne disease has to be quantifiable in an observed more than two cases of a related foodborne illness caused by the ingestion of typical food. Several diseases epidemic could be transmitted through the ingestion of contaminated food and water via contact with an infectious person. For instance, the first case of Hepatitis A found in a food service employee on Louisville US (Carrico et al., 2019) and a huge outbreak in Shanghai in quarter 1 of 1988 with 293301 confirmed cases and 32 deaths (Todd, 1997). Being proactive is a solution placing the food operator in a substantial or advantageous position over the emerging epidemics illness. In this passage, Tauxe's (2002) studies revealed that almost every year found unknown pathogens that caused foodborne illness; hence, he postulated that foodservice is facing a great challenge and public health from farm to the table is essential in the new ears.

From the history and WHO definition implied that the foodborne epidemic majorly acquired through the consumption of food, water and contact with infected person vary by type of infected diseases. However, this new emerging COVID-19 is different from the conventional foodborne pathogens where the transmission of diseases is not through the consumption of food conversely via human-to-human interaction. However, evidence has shown that COVID19 triggered mainly from an animal source precisely it first defected in Wuhan, Hubei Province, China livestock market (Rothan \& Byrareddy, 2020), and this implied that the consumption of infected livestock probably became a medium of virus transition.

Despite no conclusive evidence to show COVID-19 could be transmitted to human through food consumption (Center for Food Safety and Applied Nutrition), therefore, such 
extraordinary circumstances with very limited clinical evidence to control this pandemic thus, the foodservice operators have to be very agile and adaptive to confront the situation with various exotic ideas.

\section{Theoretical Support}

Foodservice safety remains a substantial part of our daily life and as the essential values in all aspects of the business and operations. A strong focus on consumers' safety drives the fulfillment of predictable safety needs that advocated by Maslow's Hierarchy (1943). This review reflects the heritage theory of Maslow's Hierarchy of needs. However, society and technology are continually emerging in the field of safety, the paramount part of making sure that safety needs work as envisioned. The general principle of Maslow's theory is the fulfillment of obligations ranges from mental and physiology motivations (Hale et al., 2019).

Undoubtedly, since coronavirus is on everyone's heart and minds these days, therefore, to pacify the consumers' surplus expectation on safety in foodservice. Foodservice operators need the extra initiative to manage the consumers' expectations and foster business continuity by reinforcing the heritage principal of security needs fulfillment where the quantum of safety needs is relatively higher during the COVID-19 outbreak. The goodness of Maslow's needs theory is the flexibility in operationalizing the theory where Hale's (2019) sstudy took the original safety need for away physical threats with the contemporary issues of personal also financial security where this implied that model is agile in adapting the change.

Against the backdrop of COVID-19, foodservice in Malaysia granted the green light to operate under the particular conditions and regulations imposed as it recognized as an essential sector. During the critical period, the foodservice sector beyond providing essential for living its need new approaches to oversees the risk balance and business continuity by surplus consumers' safety expectations.

The present preliminary review guiding with the theoretical support to initiate the practical implementation of the theory advocacy of safety needs fulfillment where this review comprises the best practices from different countries in addressing the COVID-19 impacts on foodservice operation during the outbreak. It meant to inspire foodservice operators to contribute to curbing the COVID-19, these exceptional contributions going above the common business goals of achieving astounding financial objective conversely its aim to mitigate the impact of the financial burden and managing behavioral objectives.

\section{The Interim Preventive Measure}

During the COVID-19 outbreak, the only survival opportunity is to embrace "change," the term change recognized as the ability to react to the internal or external needs in the present or future (Todnem By, 2005). The author shows through practical examples of how the foodservice operators mitigate the risk of disease infection. All these changes are the new beginnings to acquire new substantial survival skills in fostering business continuity through the extra precautionary measure in border aspects.

Table 1.0 demonstrated that foodservice operators putting efforts in ensuring human capital well protected in executing change. The changes not merely imposed on internal employees; it involves the transformation of consumers' behavior in dealing with food service.

The mindset needs to change from the conventional touchpoints based business to touchless practices. For instance, dine-in changed to delivery with self-pickup by fast-food chains like 
Burger King, KFC, and Pizza Hut. The change in sales channels from table to home is prominent. It is inevitable to change the operating model to prevent cross-infection during human interaction. The suggestive evidence that COVID-19 transmitted through human touchpoints (Singhal, 2020; Huang et al, 202; Lillie et al., 2020) supports the change of contactless model. Therefore, the advocacy of appropriate social distancing is paramount important. A study revealed by Baker et al. (2020) on consumer spending in the United States shown that food delivery service is increasing during the coronavirus pandemic period. Globally, food delivery service estimated worth more than US\$ 35 billion annually and forecasted future outlook to reach US $\$ 365$ billion by 2030 (The ASEAN Post Team, 2020).

Precisely the implementation of contactless narrowed to self-collection areas that pre-fixed in the eateries compound; for instance, the foodservice delivers partners Deliveroo in the United Kingdom where riders leave food at customers' doors instead of handling to them in person. Some pieces of evidence suggested COVID-19 disseminated through the airborne route (Xiao\& Torok, 2020). Rigorous personal hygiene is equally essential with regular hand washing with an alcohol-based hand sanitizer and an infectious agent's remover. The persistent use of hand sanitizer would able to reduce the risk of inter-transfer of infectious (Bondurant, Duley, \& Harbell, 2019). Edmonds et al. (2012) study in foodservice hand hygiene regimes revealed that the use of alcohol-based hand rub adjunct with a wash-sanitize regimen could reduce the risk of infection transmission in food service facilities. Furthermore, food operators imposing responsibility to individual staffs align with the high-quality prospects in safety; for instance, Grab food Philippine is insuring the delivery employees to sanitize and disinfect their delivery tools regularly.

Strengthen the gate by examining employees' body temperature to ensure employees are in good condition before start work where fever is a clinical symptom that easy to administer by using a digital body thermometer. Clinical shreds of evidence suggest that $98 \%$ of the infected patients notably presented with body temperature more than $38^{\circ} \mathrm{C}$ (Huang et al., 2020). Therefore, this easy administered preventive measure received significant attention for judging the employees' well-being where the body temperature should below $38^{\circ} \mathrm{C}$ threshold before carrying on his duty of the day

Beyond the social distancing advocacy by the healthcare professional, self-protection with a medical mask is an essential external protective shed. Hence, making it happen by equipping surgical masks in work for all the employees that required working in the food premises. Although, according to WHO recommendation person who needs surgical mask are those who are taking care of suspected COVID-19 infected person.

Besides, according to Feng et al. (2020), a different country has a different recommendation for medical mask-wearing. For instance, Hong Kong advocate mask-wearing in crowded public places such as riding public transportation. Singapore promotes medical mask usage if individuals show respiratory symptoms, such as runny nose and cough, where visible upper respiratory symptoms appear.

In short, surgical mask-wearing based on the symptomatic recommendation. However, from the risk management perspective, foodservice operators have the responsibility to determine what their industry has to contribute to mitigating the risk of disease exposure. Some good practices in foodservice demonstrated more prudent precautionary action such as myBugerLab, EPIC food hall in Malaysia that making mask-wearing is a necessary preventive measure. The 
objective is to foster the goodness of employees and customer's well-being at the same time, reinforce the consumer confidence toward the foodservice providers.

Table 1: A Preliminary Study of the Preventive Measure Actions Imposed During

COVID-19 Pandemic

\begin{tabular}{|c|c|c|c|}
\hline Food operators & Employees preventive measure action & Country & Source \\
\hline myBurgerLab & $\begin{array}{l}\text { - Wear surgical mask, temperature } \\
\text { checks for } \\
\text { respective delivery riders }\end{array}$ & Malaysia & $\begin{array}{l}\text { Vulcan Post } \\
\text { (Chai, 2020) }\end{array}$ \\
\hline EPIC Food Hal & $\begin{array}{l}\text { - Wear surgical mask, temperature } \\
\text { checks, contactless pick-up }\end{array}$ & Malaysia & $\begin{array}{l}\text { Vulcan Post } \\
\text { (Chai, 2020) }\end{array}$ \\
\hline GrabFood & $\begin{array}{l}\text { - Contactless delivery of food service } \\
\text { - Facilitate easy access to sanitizer / } \\
\text { disinfectant refill stations for drivers to } \\
\text { disinfect their delivery bags } \\
\text { - Safety online to assist staff safety } \\
\text { enquiry } \\
\text { - Wear surgical mask } \\
\text { - Practices regular hand washing with } \\
\text { soap }\end{array}$ & Philippine & $\begin{array}{l}\text { Philstar } \\
\text { Global (2020) }\end{array}$ \\
\hline Illinois Bars & $\begin{array}{l}\text { - Offering delivery and curbside services } \\
\text { will be able to remain open }\end{array}$ & United State & Miller (2020) \\
\hline McDonald's & $\begin{array}{l}\text { - Staff wash their hands every } 30 \\
\text { minutes. Temperature checks, } \\
\text { including security guards and app- } \\
\text { based delivery partners }\end{array}$ & Philippine & $\begin{array}{l}\text { ABS-CBN } \\
\text { News }(2020)\end{array}$ \\
\hline Deliveroo & - Contactless drop off point & $\begin{array}{l}\text { United } \\
\text { Kingdom }\end{array}$ & Lomas (2020) \\
\hline Burger King & - Drive-thru touchless experience & United States & $\begin{array}{l}\text { Deabler } \\
(2020)\end{array}$ \\
\hline $\mathrm{KCF}$ & - Contactless' delivery, self-collect & Malaysia & $\begin{array}{l}\text { New Straits } \\
\text { Times }(2020)\end{array}$ \\
\hline Pizza Hut & - Contactless' delivery, self-collect & Malaysia & $\begin{array}{l}\text { New Straits } \\
\text { Times }(2020)\end{array}$ \\
\hline Subway & $\begin{array}{l}\text { - Increase cleaning frequency } \\
\text { Sanitizing restaurant } \\
\text { - Reinforce existing health and safety } \\
\text { protocols } \\
\text { - Interim suspended dine-in model } \\
\text { - Implement takeout-only model } \\
\end{array}$ & United States & $\begin{array}{l}\text { Subway } \\
\text { Corporate } \\
\text { website }\end{array}$ \\
\hline
\end{tabular}

In an uncertain business environment, the speed of change is the main survival key to safeguard the business where changes involve from human to non-humanic change also the collaboration with third party. For instance, during the pandemic period many foodservice operators leverage on the food delivery service providers to retain the business operation and reduce financial burden by temporary converting the brick-and-mortar premises to ecommerce platform. 
An excellent practice by Starbuck China, switching from the traditional B2C model with the complement of digitalization. Where consumers able to order through the Starbuck application with the incorporation of contactless delivery service to enable customers to continue to enjoy coffee. Aforesaid implies that digitalizing business operations allow foodservice providers to continue business during a tough time under the pressure of pandemic.

Enormous contribution then merely supplies hygienic food during the pandemic outbreak, particularly Halal foodservice, indeed amplifying the sound Halal practices that include personal hygiene, attire, and hardware in foods and drink processing and (Ambali \& Bakar, 2014).

\section{Boosting the Foodservice Long Term Outlook}

The invisible force of fear emotion during pandemic foster the change of consumer behavior to more defensive responses to the surrounding environment (Van Bavel et al., 2020), where consumers have actively isolated themselves with the contact of people in an appreciate distance to avoid the risk of infection. The advocacy of unprecedented self-distancing approaches cultivated the awareness of self-health and self-protection awareness to people; this sheds light on the need in foodservice to provide appreciate safety distance in the layout design in the future. Past studies in space layout planning explained well that space separation could provoke positive and negative reactions toward the restaurant (Robson, 1999); therefore, appropriate space distancing might benefiting in the epidemic prevention and evolves as the basic need.

Also, A study conducted by Lu et al. (2020) with affiliation with Guangzhou Center for Disease Control and Prevention show that the potential of COVID-19 transmission through air droplet transmission in restaurant exist hence suggest to improve the restaurant air ventilation and distance between tables. This further urge the essential of safety layout design in the restaurant also the air ventilation playing a paramount role in determining the well-being of consumers.

Insights learned from the limited clinical and scientific findings under this unprecedented pandemic situation. Enable the foodservice industry to survive in short-term and better development in a long-term approach in preventing any epidemics diseases as science discovered new foodborne illnesses every year. It does not mean that foodservice replicates the preventive measure as a short-term solution literally; it needs adjustment to suit each foodservice nature and improve its operation extensive in the long-term precautionary policy. The clinical shreds of evidence provide a good conceptualization platform for foodservice operators in planning their restaurant atmospherics factors that enable them to improve community health and reduce the risk of disease infection.

Besides, the interim change of operating model from dine-in to take-out with the collaboration with third parties delivery service providers provides additional channels to expand sales opportunities. Moreover, the start of e-payment, mobile ordering could be a potential foodservice trend that evolved its popularity after this pandemic crisis.

\section{Conclusion}

In the short-term behavior change from foodservice operators and consumers is inevitable. To date still, minimal numeric parameters to justify the best preventive measures and scientific evidence to ensure the best precautionary action to get rid of this pandemic dissemination. Foodservice providers strongly recommended to practices more preventive measure to 
safeguard the consumers and employees well-being and continue to change, to improve it and make it better precautionary measure in foodservice.

Well, each approach could be implemented independently and jointly as the preventive measure rarely cannibalizing in favor of foodservice types. The ultimate survival is implementing agile change and continue to embrace change in the aspect of food safety beyond the general daily principal, also spontaneous incidents like an epidemic outbreak.

To Summaries, precautionary plan and incorporating life science approach allows food operators to put the best foot forward of what consumers want in the future, and what is inevitable to provide for profit.

Limitation of this review: This review based on the limited evidence published on journals and electronic news platform that relevant to foodservice against foodservice sector.

Funding: This paper has received no funding.

Conflicts of Interest: The authors declare no conflict of interest.

\section{References}

Ahmad, R. (2020). With latest jump, Malaysia now has fourth highest number of Covid-19 cases in Asia. Retrieved from https://www.thestar.com.my/news/nation/2020/03/19/with-latest-jump-malaysia-nowhas-third-highest-covid-19-cases-in-asia

Ambali, A. R., \& Bakar, A. N. (2014). People's awareness on halal foods and products: potential issues for policymakers. Procedia-Social and Behavioral Sciences, 121, 3-25.

ASEAN Post Team. (2020). Food Delivery on The Rise In ASEAN. Retrieved from https://theaseanpost.com/article/food-delivery-rise-asean

Bondurant, S. W., Duley, C. M., \& Harbell, J. W. (2019). Demonstrating the persistent antibacterial efficacy of a hand sanitizer containing benzalkonium chloride on human skin at 1,2, and 4 hours after application. American journal of infection control, 47(8), 928-932.

Baker, S. R., Farrokhnia, R. A., Meyer, S., Pagel, M., \& Yannelis, C. (2020). How Does Household Spending Respond to an Epidemic? Consumption During the 2020 COVID19 Pandemic (No. w26949). National Bureau of Economic Research.

Carrico, R. M., Balcom, D., Mason, D., Denker, A. G., Holland, A., Buckner, K. A., ... \& Trail, W. (2019). Multistate Hepatitis an Outbreak: Vaccination of Food Service Workers as Part of the Kentucky Outbreak Response. Journal of Refugee \& Global Health, 2(1), 16.

Center for Food Safety and Applied Nutrition. Food Safety and the Coronavirus Disease 2019 (COVID-19). (2020). Retrieved from https://www.fda.gov/food/food-safety-duringemergencies/food-safety-and-coronavirus-disease-2019-covid-19

Chai, J. (2020). 5 F\&B Founders Break Down Their Game Plan on Surviving This Partial Lockdown. Retrieved from https://vulcanpost.com/692511/malaysia-fnb-restaurantssurvival-strategies-covid-19/

Chin, J. L. (2011). Women and Leadership: Transforming Visions and Current Contexts. Forum on Public Policy: A Journal of the Oxford Round Table, (2), 1-12. 
Deabler, A. (2020). Restaurant chains modify service as coronavirus outbreak continues. Retrieved from https://www.foxnews.com/food-drink/restaurant-chains-modifyservice-coronavirus-outbreak

Edmonds, S. L., McCormack, R. R., Zhou, S. S., Macinga, D. R., \& Fricker, C. M. (2012). Hand hygiene regimens for the reduction of risk in food service environments. Journal of food protection, 75(7), 1303-1309.

Feng, S., Shen, C., Xia, N., Song, W., Fan, M., \& Cowling, B. J. (2020). Rational use of face masks in the COVID-19 pandemic. The Lancet Respiratory Medicine.

Food delivery services share measures to prevent COVID-19 transmission. (2020). Retrieved from https://www.philstar.com/lifestyle/food-and-leisure/2020/03/16/2001342/fooddelivery-services-share-measures-prevent-covid-19-transmission

Foodborne disease outbreaks: guidelines for investigation and control. (2008). Retrieved from: https://www.who.int/foodsafety/publications/foodborne_disease/outbreak_guidelines. pdf

Frequently asked questions (FAQs) on movement control order. (2020). Retrieved from https://www.thestar.com.my/news/nation/2020/03/17/frequently-asked-questionsfaqs-on-movement-control-order

Hale, A. J., Ricotta, D. N., Freed, J., Smith, C. C., \& Huang, G. C. (2019). Adapting Maslow's hierarchy of needs as a framework for resident wellness. Teaching and learning in medicine, 31(1), 109-118.

Huang, C., Wang, Y., Li, X., Ren, L., Zhao, J., Hu, Y., ... \& Cheng, Z. (2020). Clinical features of patients infected with 2019 novel coronavirus in Wuhan, China. The Lancet, 395(10223), 497-506.

Jollibee, McDonald's take steps to stay open during COVID-19 quarantine. (2020). Retrieved from https://news.abs-cbn.com/business/03/16/20/jollibee-mcdonalds-take-steps-tostay-open-during-covid-19-quarantine

Kanyakumari, D. (2020). 'We can do this', say Malaysian social media users after extension of movement control order. Retrieved from https://www.channelnewsasia.com/news/asia/malaysia-movement-control-ordercovid19-muhyiddin-yassin-12575512

KFC, Pizza Hut implement 'contactless' delivery, self-collect options during MCO. (2020). Retrieved from https://www.nst.com.my/news/nation/2020/03/575717/kfc-pizza-hutimplement-contactless-delivery-self-collect-options-during

Lillie, P. J., Samson, A., Li, A., Adams, K., Capstick, R., Barlow, G. D., .. \& Ivan, M. (2020). Novel coronavirus disease (Covid-19): the first two patients in the UK with person to person transmission. Journal of Infection.

Lomas, N. (2020). Europe's Deliveroo and Glovo switch on contactless delivery during COVID-19 pandemic. Retrieved from https://techcrunch.com/2020/03/12/europesdeliveroo-and-glovo-switch-on-contactless-delivery-during-covid-19-pandemic/

Lu, J., Gu, J., Li, K., Xu, C., Su, W., Lai, Z., ... \& Yang, Z. (2020). COVID-19 Outbreak Associated with Air Conditioning in Restaurant, Guangzhou, China, 2020. Emerging infectious diseases, 26(7).

Miller, L. (2020). All Illinois Bars, Restaurants to Close for Two Weeks Due to COVID-19. Retrieved from https://www.riverfronttimes.com/foodblog/2020/03/15/all-illinoisbars-restaurants-to-close-for-two-weeks-due-to-covid-19

Robson, S. K. (1999). Turning the tables: The psychology of design for high-volume restaurants. Cornell Hotel and Restaurant Administration Quarterly, 40(3), 56-63.

Rothan, H. A., \& Byrareddy, S. N. (2020). The epidemiology and pathogenesis of coronavirus disease (COVID-19) outbreak. Journal of autoimmunity, 102433. 
Singhal, T. (2020). A Review of Coronavirus Disease-2019 (COVID-19). The Indian Journal of Pediatrics, 1-6.

The Subway Group (2020, April). Retrieved from https://www.subway.com/enUS/SubCulture/coronavirus-and-your-safety

Tauxe, R. V. (2002). Emerging foodborne pathogens. International journal of food microbiology, 78(1-2), 31-41.

Todd, E. C. (1997). Epidemiology of foodborne diseases: a worldwide review.

Todnem By, R. (2005). Organisational change management: A critical review. Journal of change management, 5(4), 369-380.

Van Bavel, J. J., Boggio, P., Capraro, V., Cichocka, A., Cikara, M., Crockett, M., ... \& Ellemers, N. (2020). Using social and behavioural science to support COVID-19 pandemic response.

World Health Organization. (2020). WHO Director-General's opening remarks at the media briefing on COVID-19 - 13 April 2020. Retrieved from https://www.who.int/dg/speeches/detail/who-director-general-s-opening-remarks-atthe-media-briefing-on-covid-19--13-april-2020

Xiao, Y., \& Torok, M. E. (2020). Taking the right measures to control COVID-19. The Lancet Infectious Diseases. 